\title{
Distribution of Risso's dolphin (Grampus griseus, Cuvier 1812) in Chilean waters
}

\author{
Distribución del calderón gris (Grampus griseus, Cuvier 1812) en aguas chilenas \\ Carlos Olavarría ${ }^{1}$, Anelio Aguayo-Lobo ${ }^{2}$ and Rolando Bernal ${ }^{3}$ \\ ${ }^{1}$ University of Auckland, School of Biological Sciences. \\ Private Bag 92019, Auckland, New Zealand. \\ c.olavarria@auckland.ac.nz \\ ${ }^{2}$ Instituto Antártico Chileno, Departamento Científico. \\ Casilla 16521, Correo 9, Providencia, Santiago, Chile. \\ ${ }^{3}$ Universidad de Valparaíso, Facultad de Ciencias del Mar \\ Casilla 13-D, Viña del Mar, Chile.
}

\begin{abstract}
Resumen.- En este trabajo se revisa la información del calderón gris Grampus griseus en aguas chilenas. En base al análisis de 44 registros, la distribución a lo largo de la costa chilena parece ser continua entre los $20^{\circ} 13^{\prime} \mathrm{S}$ y $40^{\circ} \mathrm{S}$, sugiriendo que los registros más australes en Chile $\left(\sim 52^{\circ} \mathrm{S}\right)$ podrían corresponder a calderones grises provenientes del Océano Atlántico. Los registros en Chile muestran un aumento durante el verano austral e indican una preferencia por aguas sobre los $1000 \mathrm{~m}$ de profundidad. Varamientos masivos, interacciones con pesquerías y asociaciones con otras especies de cetáceos son también revisadas.

Palabras clave: Calderón gris, Grampus griseus, distribución, Chile, Pacífico Sur Este.
\end{abstract}

\begin{abstract}
Here we review the knowledge of Risso's dolphin Grampus griseus in Chilean waters. Based on analysis of 44 records, this species appears to have a continuous distribution along the Chilean coast between $20^{\circ} 13^{\prime}$ 'S and $40^{\circ} \mathrm{S}$ and we suggest that the reported southernmost record from Chile $\left(\sim 52^{\circ} \mathrm{S}\right.$ ) could be Atlantic Risso’s dolphins. The Chilean records show a peak during the austral summer and indicate a preference for waters over $1000 \mathrm{~m}$ in depth. Mass stranding, interaction with fisheries, and associations with other cetaceans species are also reviewed.

Keywords: Risso's dolphin, Grampus griseus, distribution, Chile, Eastern South Pacific.
\end{abstract}

The occurrence of Risso's dolphin Grampus griseus in Chilean waters was insufficiently documented, with only one published reports of sightings (Aguayo-Lobo 1975) and a small number of notes regarding collections of osteological material (Venegas and Sielfeld 1978, Sielfeld 1980, Guerra et al. 1987, Fernández 1987). Recently, knowledge of $G$. griseus in Chile has increased considerably, due to new sightings in the northern waters (Findlay et al. 1998 ${ }^{1}$ ).

Here we attempt to integrate all available information about $G$. griseus in Chile in order to resolve

\footnotetext{
${ }^{1}$ Findlay K, R Pitman, T Surui, K Sakai, P Ensor, H Iguakami, D Ljungblad, H Shimada, D Thiele, K Van Waeerebek, R HuckeGaete and GP Sanino. 1998. 1997-1998 IWC/Southern Ocean Whale and Ecosystem Research (IWC/SOWER) Blue Whale Cruise-Chile. 39 pp. Available from IWC, The Red House, Station Road, Impington, Cambridge, CB4 4NP, United Kingdom.
}

questions regarding its range and distribution. We include information from unpublished reports not considered previously, seek to clarify erroneously interpreted records and present further details for previously published records to assess the possible interaction with some fisheries.

Forty-four records of $G$. griseus were available (Table 1, Figure 1). The two records of unidentified whales observed off Valparaíso in November 1964 (Clarke et al. 1978) are also likely to represent $G$. griseus based on the external description of the animals and a published photograph (see Figure 1, Plate III in Clarke et al. 1978).

The distribution of Risso's dolphin in Chilean waters appears to be continuous, from $20^{\circ} 13^{\prime} \mathrm{S}$ in the north to the south, with the southernmost record at $40^{\circ} \mathrm{S}$ in the Eastern South Pacific. The previously reported southernmost record in Chilean waters ( $\sim 52^{\circ} \mathrm{S}$; Venegas and Sielfeld 1978, Sielfeld 1980) corresponds to bone material collected near the eastern opening of Straits of Magellan. Aguayo et al. (1998b) erroneously located these records at the Patagonian channels region and 
such, included them among the records for this species from the Pacific coast. Given the proximity of the collection site to the Atlantic Ocean we suggest instead that these specimens were most likely derived from the Atlantic population of Risso's dolphin and not from the Pacific. Similar reason has been applied to the assignment of false killer whale records in this area (Koen Alonso et al. 1999). There are no records of $G$. griseus from Chile's oceanic islands in the South Pacific Ocean (Juan Fernández Archipelago, Easter Island, San Felix, San Ambrosio and Sala y Gómez Islands), suggesting a possible preference for temperate waters of the Humboldt current rather than for warmer waters like those founded to the west into the Pacific Ocean (Bernal et al. 1982).

Sightings of Risso's dolphins are generally in waters over $1000 \mathrm{~m}$ in depth. A comparative distribution has been observed for this species in the northern Gulf of Mexico, where they prefer a narrow core habitat between the $350 \mathrm{~m}$ and $975 \mathrm{~m}$ isobaths. This depth range is known to have a high productivity and concentration of prey species (Baumgartner 1997). A similar physiogeographic relationship situation may explain the high number of sightings in the north/central part of Chile, where upwelling and coastal fronts results in highly productive waters, which sustain several largescale fisheries (Bernal et al. 1982).

The majority of records for G. griseus concentrate within austral summer months in northern waters. This could be related to seasonal movements into the northern and central waters of Chile. This is supported by the lack of sightings of this species over five cruises (1993, 1994 and 1995) between Valparaíso and Eastern Island, off central Chile, during the winter months (Aguayo-Lobo et al. 1998a).

Inter-specific association have been reported for $G$. griseus with several cetacean species (see Kruse et al. 1999), including bottlenose dolphins Tursiops truncatus, as was observed on two occasions by Findlay et al. (1998) ${ }^{1}$. Mixed-species aggregations with Lagenorhynchus australis (Aguayo-Lobo 1975) and with Lissodelphis peronii (Hucke-Gaete 2000²) have also been reported, but were not included in the worldwide review of G. griseus of Kruse et al. (1999).

Mass strandings of this species are uncommon. On the eastern coast of North America, 30 strandings

\footnotetext{
${ }^{2}$ Hucke-Gaete R. 2000. Crucero de la Comisión Ballenera Internacional en la zona económica exclusiva de Chile (1999/2000): Informe del observador científico. Subsecretaria de Pesca, Ministerio de Economía, Fomento y Reconstrucción, República de Chile. 40 pp.
}

incidents involved mostly single animals, with a maximum of five dolphins (Reiger 1980, Leatherwood et al. 1980). In South America, Goodall and Schiavini $(1992)^{3}$ reported eight strandings from Tierra del Fuego, Atlantic Ocean. The majority of these consisted of three or four dolphins, except for two instances where groups of 14 and 15 individuals stranded together. The first mass stranding of G. griseus from the Pacific coast of South America was recorded in Santa Maria island $\left(37^{\circ} \mathrm{S}, 73^{\circ} 30^{\prime} \mathrm{W}\right)$ in 1992 , when 14 animals stranded alive. They were returned to the water by local fishermen and three dolphins subsequently washed up dead (Brito 1996 ${ }^{4}$ ).

Two records of G. griseus are of special interest with respect to possible interaction with commercial fisheries. In March 1989, five G. griseus were entangled and drowned in nets of a boat fishing for Pacific jack mackerel (Trachurus symetricus murphyi), probably in the gulf of Arauco $\left(37^{\circ} \mathrm{S} ; 73^{\circ} \mathrm{W}\right)^{5,6}$. No further data were available, except for photographs of one specimen. Several incidental catches have also been recorded from Peru (Vidal $1992^{7}$ ). The Gulf of Arauco record is the first documented evidence of fishery interaction with Risso's dolphin at Chilean waters. In spite of the principal prey species for $G$. griseus being cephalopods, fish may be taken occasionally (Leatherwood and Reeves 1983, Martin, 1990). Therefore, G. griseus may feed on T. murphyi in Chilean waters, at least in some areas, and so be at risk from entanglement.

${ }^{3}$ Goodall RNP and A Schiavini. 1992. Varamientos de delfín gris Grampus griseus, en las costas del extremo sur sudamericano. V Reunión de especialistas en mamíferos acuáticos de América del Sur. 28 septiembre-2 octubre, Buenos Aires, Argentina.

${ }^{4}$ Brito JL. 1996. Nuevos registros de cetáceos para las aguas de Chile central. VII Reunión de especialistas en mamíferos acuáticos de América del Sur y I Congreso de la Sociedad Latinoamericana de Especialistas en Mamíferos Acuáticos. 22-25 octubre, Viña del Mar, Chile.

${ }^{5}$ E Tarifeño personal communication to A Aguayo-Lobo, November $12^{\text {th }}$ 1992. Facultad de Ciencias Biológicas y Recursos Naturales, Universidad de Concepción, Casilla 2407, Concepción, Chile.

${ }^{6}$ Olavarría C, R Bernal, E Tarifeño and A Aguayo-Lobo. 1999. Impacto de las pesquerías de Dissostichus eleginoides y Trachurus murphyi sobre Grampus griseus en aguas de Chile central. XIX Congreso de Ciencias del Mar, 3 a 7 mayo 1999, Antofagasta, Chile.

${ }^{7}$ Vidal O. 1992. Los mamíferos marinos del Océano Pacífico Sudeste (Panamá, Colombia, Ecuador, Perú y Chile): diagnóstico regional. Informes y Estudios del programa de Mares regionales del PNUMA No142. 25 pp. 


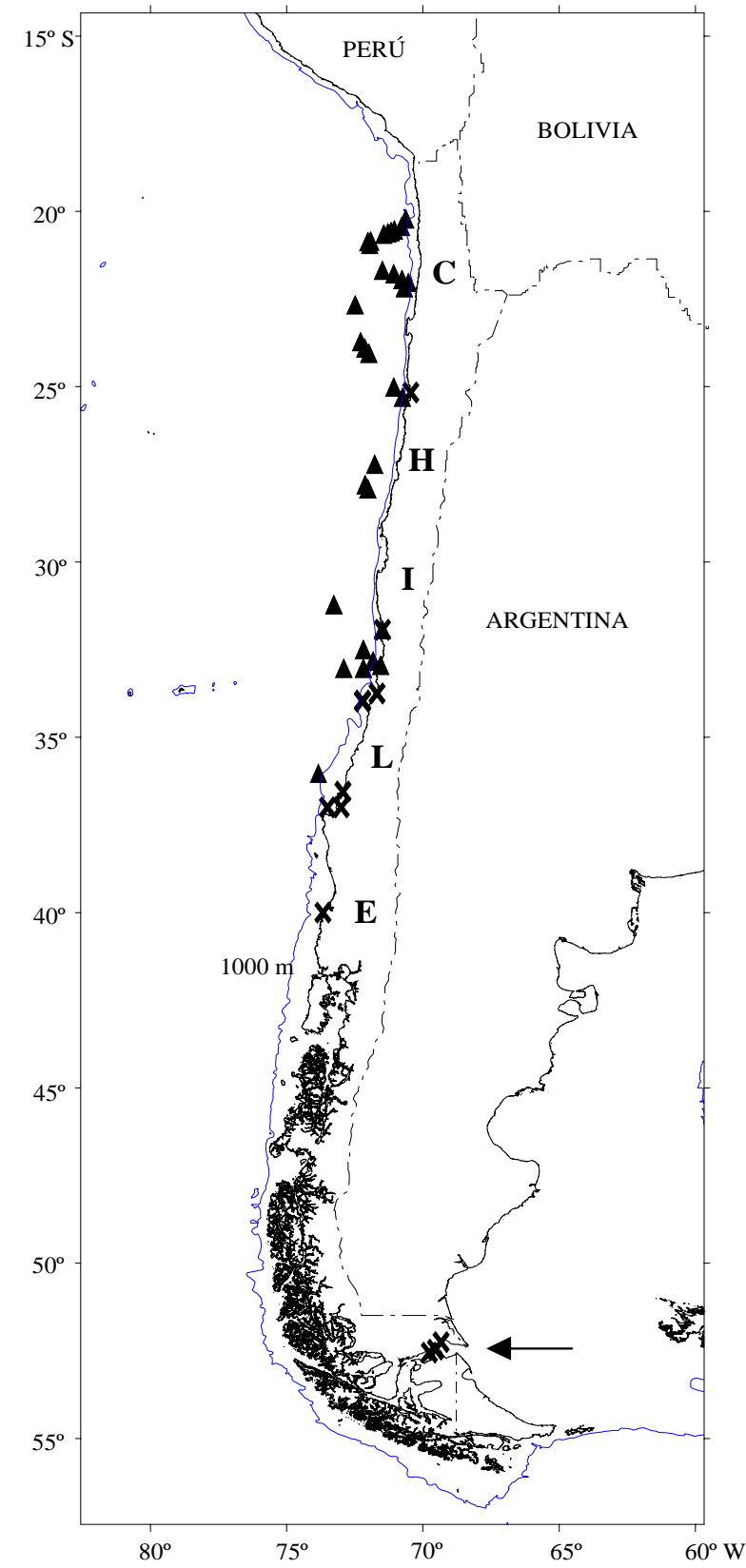

Figure 1

Records of Grampus griseus in Chilean waters. Triangles indicate sightings and crosses show the location of stranded animals or skeleton remains. The records reported by Norris $(1968)^{11}$ off Valparaíso and Sielfeld (1980) at Magallanes are not shown due to lack of geographic information. Arrow indicates records of putative Risso's dolphin from Atlantic population.

Registros de Grampus griseus en aguas chilenas. Triángulos indican avistamientos y cruces muestran localización de animales varados o restos óseos. Los registros reportados por Norris $(1968)^{11}$ frente a Valparaíso y por Sielfeld (1980) en Magallanes no son mostrados debido a la carencia de información geográfica. La flecha indica los registros de supuestos delfines de Risso del Océano Atlántico.
During a boat-based survey realized on 19 December 1991, which aimed to corroborate the reports of Valparaíso fishermen of lost catches from bottom-set longlines for Patagonian tooth fish (Dissostichus eleginoides) due to predation by sperm whales (Physeter macrocephalus), a group of 15 Risso's dolphins were observed for a period of $10 \mathrm{~min}$, approximately 15 nautical miles off Valparaíso. The closest approach to the survey vessel was $50 \mathrm{~m}$, with the dolphins moving along the starboard and poop of the boat $^{8}$. Sea depth at the sighting location was $1600 \mathrm{~m}$. The fish captured on the longline haul were undamaged.

Aguayo-Lobo et al. (1992) noted that marine mammals interactions with fisheries do not always result in direct competition for common resources, as was postulated by Northridge (1984). However, such interactions may results in competition between marine mammals and large fish competing by food. Although the Risso's dolphins off Valparaíso in 1991 did not damage the longlines nor fish caught on them, the Risso's dolphin presence may be related to the fishery operations in a common feeding area for G. griseus and $D$. eleginoides, plenty in squids (Dosidicus gigas). G. griseus feed mainly on cephalopods (Clarke and Pascoe 1985, Würzt et al. 1992) as well as D. eleginoides (Movillo and Bahamonde 1971). Worldwide, there are a few reported interactions between Risso's dolphin and fisheries. Although never taken in large numbers, $G$. griseus have been taken periodically in small whale fisheries and as by-catch in other fisheries at Europe, Black Sea, the lesser Antilles, Japan, North America, Peru and some Indo-Pacific islands such as in the Solomon Islands, Indonesia and Sri Lanka (Leatherwood and Reeves 1983, Northridge 1984, Martin 1990, Vidal 1992 ${ }^{7}$, Kruse et al. 1999).

The data summarized in this report provides a clearer understanding of the distribution, habitat, interspecies associations, strandings and fishery interactions of G. griseus in Chilean waters compared to other previously published reviews for this species (Aguayo et al. 1998b, Kruse et al. 1999), especially as the latter considered only two sightings of G. griseus for this region.

\footnotetext{
${ }^{8}$ Olavarría C and R Bernal. 1996. Registro de Cetáceos para la región de Valparaíso, Chile. VII Reunión de especialistas en mamíferos acuáticos de América del Sur y I Congreso de la Sociedad Latinoamericana de Especialistas en Mamíferos Acuáticos. 22-25 octubre, Viña del Mar, Chile.
} 


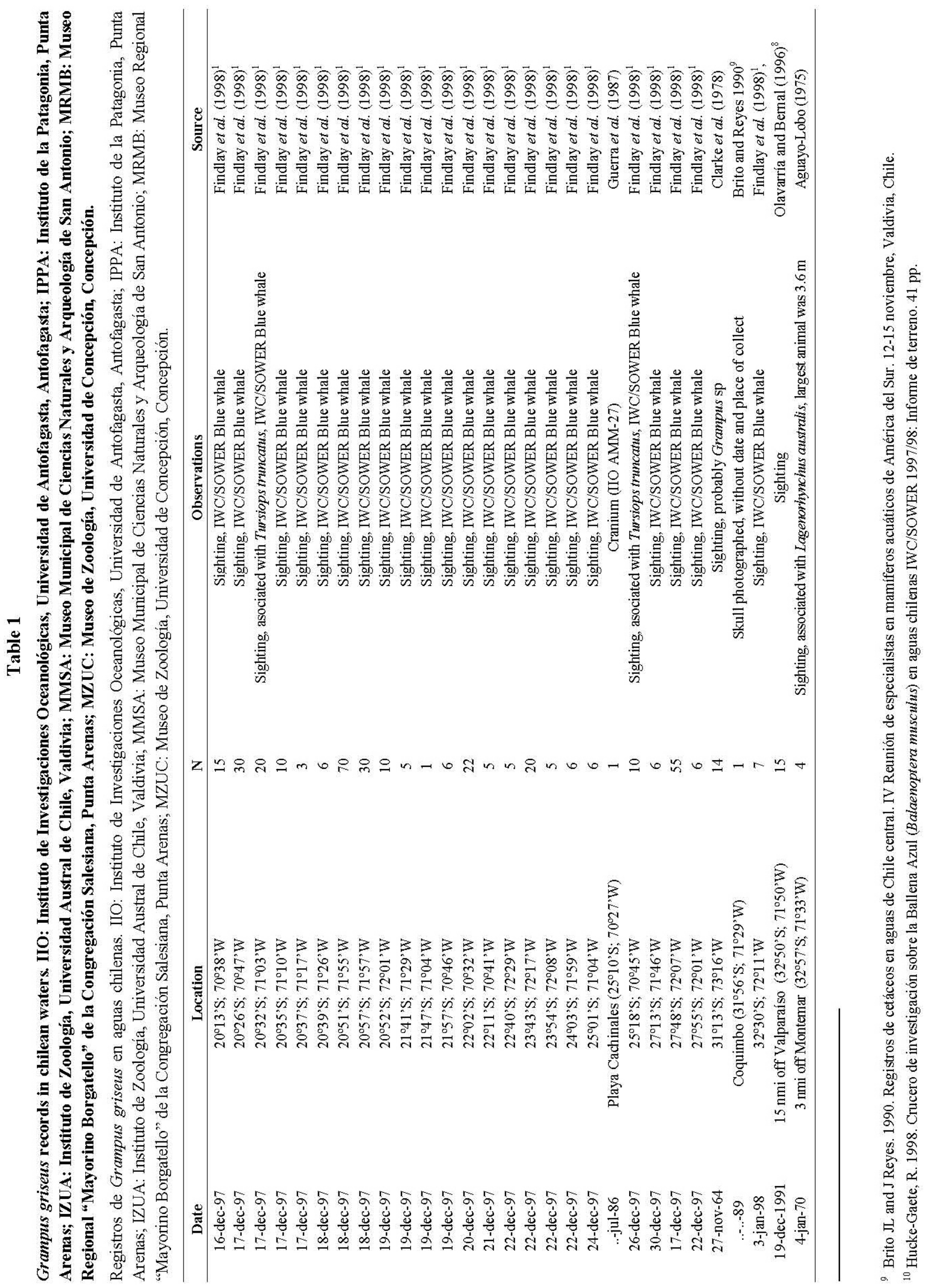



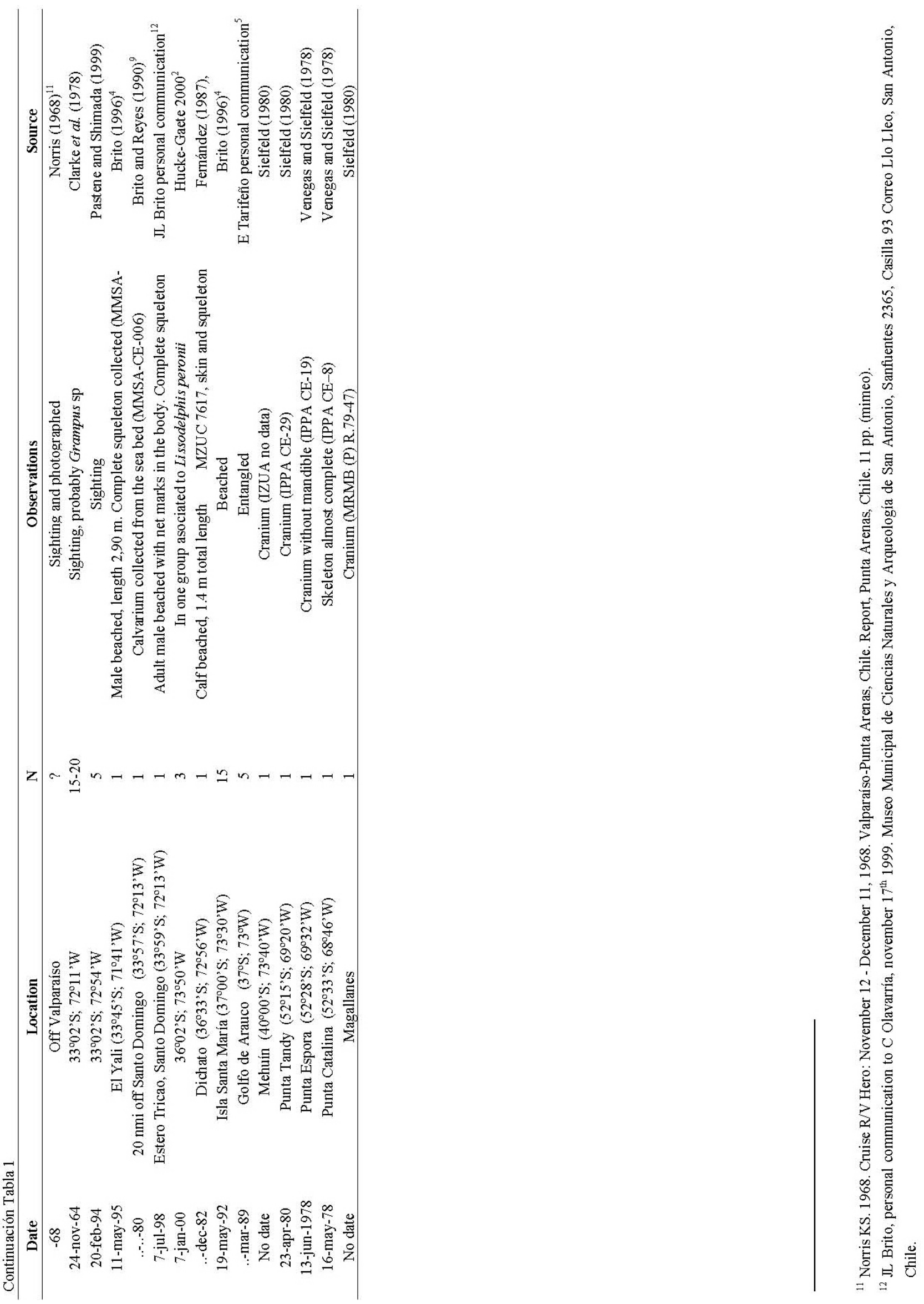


\section{Acknowledgments}

We gratefully thank to JF Moncada of the Valparaíso Fishermen Association who helped us on board the L/M Pelusa. JL Brito, J Chong, RNP Goodall, R HuckeGaete and E Tarifeño supplied us with important unpublished data. Especially, M Hughes (International Whaling Commission) provided the data of 1997/98 IWC/SOWER cruise in the north of Chile. AK Lescrawaet, J Gibbons and Y Vilina helped us with the first draft of this note. K Russell, N Patenaude and M Dalebout provided important help with the current version of this manuscript, including its translation into english.

\section{Literature Cited}

Aguayo-Lobo A. 1975. Progress report on small cetacean research in Chile. Journal of the Fisheries Research Board of Canada 32(7): 1123-1143.

Aguayo-Lobo A., JC Cárdenas and D Torres. 1992. Análisis de los avistamientos de Eubalaena australis (Desmoulins 1822) en aguas chilenas, desde 1983 hasta 1989. Serie Científica INACH 42: 77-91.

Aguayo-Lobo A, R Bernal, C Olavarría, V Vallejos and R Hucke-Gaete. 1998a. Cetofauna de las aguas frente a Chile central, incluyendo las de Isla de Pascua. Revista de Biología de Marina y Oceanografía 33(1): 101-123.

Aguayo-Lobo A, D Torres and J Acevedo. 1998b. Los mamíferos marinos de Chile: I. Cetacea. Serie Científica INACH 48: 19-159.

Baumgartner MF. 1997. The distribution of Risso's dolphin (Grampus griseus) with respect to the physiogeography of the northern Gulf of Maine. Marine Mammal Science 13(4): 614-638.

Bernal P, F Robles and O Rojas. 1982. Variabilidad física y biológica en la región meridional del sistema de corrientes Chile-Perú. FAO Fisheries Report 291: 683-711.

Clarke M and PL Pascoe. 1985. The stomach contents of a Risso's dolphin (Grampus griseus) stranded at Thurlestone, South Devon. Journal of the Marine Biological Association of the United Kingdom 65: 983986.

Clarke R, A Aguayo-Lobo and S Basulto del Campo. 1978. Whale observation and whale marking off the coast of Chile in 1964. Scientific Report of Whales Research Institute 30: 117-182.

Fernández J. 1987. Nuevos registros de parásitos en mamíferos marinos chilenos. Parasitol al día 11: 120-125.

Guerra C, K Van Waerebeek, G Portflitt and F Luna. 1987. Presencia de cetáceos frente a la segunda región de Chile. Estudios Oceanológicos 6: 87-97.
Koen Alonso M, SN Pedraza, A Schiavini, RNP Goodall and E Crespo. 1999. Stomach contents of false killer whales (Pseudorca crassidens) stranded on the coast of the Strait of Magellan, Tierra del Fuego. Marine Mammal Science 15(3): 712-724.

Kruse S, DK Caldwell and MC Caldwell. 1999. Risso's dolphin Grampus griseus (G. Cuvier, 1812). In: Ridgway SH and R Harrison (eds), Handbook of Marine Mammals. Volume 6. The Second Book of Dolphins and the Porpoises: 183-212. Academic Press. New York

Leatherwood S, WF Perrin, VL Kirby, CL Hubbs and M Dahlheim. 1980. Distribution and movements of Risso's dolphin, Grampus griseus, in the Eastern North Pacific. Fishery Bulletin 77(4): 951-963.

Leatherwood $S$ and $\mathbf{R}$ Reeves. 1983. The Sierra Club handbook of whales and dolphins. Sierra Club Books, San Francisco.

Martin AR. 1990. The Encyclopaedia of whales and dolphins. Portland House Publ.

Mitchell E. 1975. Porpoise, dolphin and small whale fisheries of the world. Status and problems. IUCN Monograph $N^{\circ} 3$ : 86.

Movillo $\mathbf{J}$ and $\mathbf{N}$ Bahamonde. 1971. Contenido gástrico de Dissostichus amissus Gill y Townsend en San Antonio. Noticiario Mensual del Museo Nacional de Historia Natural 175: 9-11.

Northridge SP. 1984. World review of interactions between marine mammals and fisheries. FAO Fisheries Technical Paper 251.

Pastene L and H Shimada. 1999. Report of a sighting survey in Chile's exclusive economic zone with comments on sei whale distribution. Anales del Instituto de la Patagonia (Chile) 27: 51-62.

Reiger G. 1980. The mysterious Grampus. Sea Frontiers, September-October: 267-270.

Ruiz VH and H Oyarzo. 1987. Mamíferos marinos en las colecciones zoológicas de la Universidad de Concepción y Museo Regional de Concepción. Comunicaciones del Museo Regional de Concepción 1: 31-40.

Sielfeld W. 1980. Mamíferos marinos en colecciones y museos de Chile. Anales del Instituto de la Patagonia, Punta Arenas (Chile) 11: 273: 280.

Venegas C and W Sielfeld. 1978. Registros de Mesoplodon layardii y otros cetáceos en Magallanes. Anales del Instituto de la Patagonia, Punta Arenas (Chile) 9: 171-177.

Würtz M, R Poggi and M Clarke. 1992. Cephalopods from the stomach of a Risso's dolphin (Grampus griseus) from the Mediterranean. Journal of the Marine Biological Association of the United Kingdom 72: 861-867. 